\title{
Strategi Komunikasi Pembangunan Marsipature Hutanabe ( Partisipatif ) Masyarakat Desa Doulu Kabupaten Karo Provinsi Sumatera Utara
}

\author{
Imam El Islamy \\ Program Studi Komunikasi dan Penyiaran Islam (S2) \\ Pascasarjana UIN Sumatera Utara \\ Email: imamzyan@gmail.com
}

\begin{abstract}
ABSTRAK
Potensi Desa Doulu yang kaya akan sumber daya alam berupa pertanian dan air panas merupakan modal utama bagi kemajuan masyarakat. Pembangunan Masyarakat Desa dengan konsep Marsipature Hutanabe sangat relevan dengan strategi komunikasi pembangunan yakni partisipatif, dengan menggunakan analisis SWOT maka semua keunggulan dan kelemahan desa Doulu dapat dilihat dan diatasi. Dengan melibatkan semua unsur yang ada baik masyarakat maupun perangkat desa maka sumber daya alam yang dimiliki oleh desa Doulu akan termaksimalkan untuk pembangunan masyarakat.
\end{abstract}

\section{Kata Kunci: Strategi, Komunikasi}

\section{PENDAHULUAN}

Prinsip dalam proses komunikasi pembangunan, pemerintah atau pihak-pihak yang memiliki ide tentang pembangunan dapat berperan sebagai sumber pesan. Pesan tersebut disebarkan kepada komunikan oleh komunikator melalui suatu saluran atau media dengan efek tertentu. Dalam proses komunikasi dapat terjadi umpan balik (feedback) dari komunikan kepada komunikator sebagai reaksi atas pesan-pesan pembangunan yang disampaikan. Era sekarang, pembangunan disegala bidang sedang giatnya dilaksanakan mulai dari perkotaan hingga ketingkat pedesaan. Demi keberhasilan pembangunan tersebut maka peran serta masyarakat dalam menentukan arah pembangunan sangatlah penting agar tujuan dari pembangunan tersebut bisa mencapai sasaran, yaitu bidang-bidang pembangunan yang dilaksanakan sesuai dengan apa yang menjadi kebutuhan masyarakat setempat. Untuk itu diperlukan komunikasi antara pemerintah sebagai pihak yang hendak membangun dengan masyarakat sebagai sasaran dari pembangunan tersebut, sehingga pembangunan yang dijalankan bisa benar-benar sesuai dengan apa yang diharapkan.

Keberhasilan pembangunan tidak lepas dari adanya komunikasi pembangunan. Komunikasi menjadi salah satu sarana yang sangat penting dalam menjaga interaksi dan hubungan antara masyarakat dengan lingkungan sosial maupun masyarakat dengan pemerintah. Luasnya wilayah Republik Indonesia dengan jenis geografi yang berbeda disetiap wilayahnya, serta budaya yang beragam menjadi satu masalah tersendiri dalam pembangunan dewasa ini, sebab kadangkala suatu program yang direncanakan tidak sesuai dengan kondisi masyarakat setempat. 
Seperti halnya desa Doulu yang terletak di Kabupaten Karo memiliki segala potensi untuk maju dan mengembangkan potensi masyarakatnya, namun itu semua seakanakan tidak digunakan untuk pembangunan desa, namun untuk kepentingan pribadi.

\section{TINJAUAN PUSTAKA}

\section{A. Strategi Komunikasi Pembangunan}

Stategi adalah cara dan atau taktik untuk mencapai tujuan atau "perencanaan dan manajemen untuk mencapai tujuan" (tidak hanya peta jalan tapi juga taktik operasionalnnya). Adapun komunikasi memiliki arti proses penerusan faktorfaktor, kepercayaan, sikap, reaksi emosi atau lain-lain pengetahuan antar individu dalam masyarakat. Komunikasi adalah proses mengubah perilaku orang lain. Proses komunikasi pada hakekatnya adalah proses penyampaian pikiran atau perasaan oleh seseorang (komunikator) kepada orang lain (komunikan). Pikiran dapat berupa gagasan, informasi, maupun opini. Adapun perasaan bisa berupa keyakinan, kepastian, keragu-raguan, kekhawatiran, kemarahan, maupun keberanian. $^{1}$

Berdasarkan model komunikasi linier yang saat ini telah berlaku menjadi komunikasi yang lebih partisipatif, unsur komunikasi ada lima yaitu: komunikator (communicator, sender, dan source), pesan (message), media (channel), komunikan (communicant, communicatee, receiver, recipient), dan efek (effect). Dengan demikian, menurut definisi ini, komunikasi adalah proses penyampaian pesan oleh komunikator kepada komunikan melalui media yang menimbulkan efek tertentu. ${ }^{2}$ Komunikasi akan berhasil apabila pikiran disampaikan dengan perasaan yang disadari, sebaliknya komunikasi akan gagal apabila sewaktu menyampaikan pikiran, perasaan tidak terkontrol. Pikiran bersama perasaan yang akan disampaikan kepada orang lain dinamakan picture in our head. Yang menjadi permasalahan adalah bagaimana caranya agar gambaran dalam benak dan isi kesadaran pada komunikator yang oleh Laswell dinyatakan sebagai pesan itu dapat dimengerti, diterima, dan bahkan dilakukan atau diterapkan oleh komunikan. ${ }^{3}$

1 Nugroho, A. Komunikasi Pembangunan dan Keterbukaan Informasi Publik dalam Kerangka Pengembangan Masyarakat Mandiri. Prosiding Seminar Nasional : Komunikasi Pembangunan Mendukung Peningkatan Kualitas Sumber Daya Manusia dalam Kerangka Pengembangan Masyarakat. Kamis, 19 November 2009. Bogor : IPB International Convention Center (IPB ICC), hal : 61-66.

${ }^{2}$ Rogers, E.M. Perspektif Baru dalam Komunikasi dan Pembangunan : Suatu Tinjauan dalam Komunikasi dan Pembangunan Perspektif Kritis, Dasmar N, penerjemah. 1985.( Jakarta: 1976. LP3ES) Terjemahan dari Communication and Development : Critical Perspectives.

3 Theodore, N., Valenzuela, Jr, A., \& Meléndez, E. Worker centers: d efending labor standards for migrant workers in the informal economy. International Journal of Manpower. 30(5), 2009 ) 422 - 436. 
Strategi komunikasi adalah paduan antara perencanaan komunikasi (Communication Planning) dengan manajemen komunikasi (Communication Management) untuk mencapai tujuan yang diinginkan. Untuk mencapai tujuan tersebut strategi komunikasi harus mampu menunjukkan bagaimana operasionalnya secara praktis harus dilakukan. Dalam arti kata bahwa pendekatan (aproach) dapat berbeda sewaktu-waktu bergantung pada situasi dan kondisi. Strategi komunikasi adalah keseluruhan perencanaaan, taktik, cara yang akan dipergunakan guna melancarkan komunikasi dengan memperhatikan keseluruhan aspek yang ada pada proses komunikasi untuk mencapai tujuan yang diinginkan.

Ada empat strategi komunikasi pembangunan yang telah digunakan selama ini. ${ }^{4}$

a) Strategi-strategi berdasarkan media (media-based strategies). Para komunikator yang menggunakan strategi ini biasanya mengelompokkan kegiatan mereka disekitar medium. tertentu yang mereka sukai. Strategi ini strategi yang paling mudah, populer, dan yang pasti kurang efektif.

b) Strategi-strategi desain instruksional. Menggunakan strategi ini pada umumnya adalah para pendidik. Strategi ini memfokuskan pada pembelajaran individu-individu yang dituju segabai sasaran yang fundamental.

c) Strategi-strategi partisipatori. Dalam strategi ini, prinsip-prinsip penting dalam mengorganisasi kegiatan adalah kerja sama komunitas dan pertumbuhan pribadi. Yang terpenting dalam strategi ini adalah pengalaman keikutsertaan sebagai seseorang yang sederajat dalam proses berbagai pengetahuan atau keterampilan.

d) Strategi-strategi pemasaran. Strategi ini tumbuh sebagai suatu strategi komunikasi yang sifatnya paling langsung dan terasa biasa.

\section{B. Prasarana Desa}

Sebagaimana kawasan yang lain, secara administratif pada kawasan pegunungan dikenal adanya desa, kecamatan, kota, kabupaten, propinsi, dan lainnya, sehingga kita juga mengenal adanya prasarana perdesaan, prasarana perkotaan, dan sebagainya.Penyediaan prasarana perdesaan bagi pengembangan kawasan pesisir sangatlah urgen, karena sebagian besar permasalahan kawasan pesisir pemecahannya sangat terkait dengan penyediaan prasarana tersebut. Prasarana dapat dianggap sebagai faktor potensial dalam menentukan

4 Mulyana, D. Membangun Komunikasi Pembangunan yang Humanistik [Kata Pengantar]. Di dalam Dilla S, penulis. Komunikasi Pembangunan : PendekatanTerpadu. Bandung : Simbiosa Rekatama Media, 2007 ) hal. 57 
perkembangan suatu wilayah perkotaan maupun perdesaan. Pembangunan wilayah tidak dapat berjalan dengan lancar jika prasarana tidak memadai.

Dalam konteks lingkungan permukiman, Undang-Undang Nomor 4 Tahun 1992 tentang Perumahan dan Permukiman memberi definisi tentang prasarana lingkungan sebagai kelengkapan dasar fisik lingkungan yang memungkinkan lingkungan perumahan dapat berfungsi sebagaimana mestinya, seperti: jalan, saluran air minum, saluran air limbah, saluran air hujan, pembuangan sampah dan jaringan listrik. Lebih jauh, kebutuhan prasarana dasar permukiman menurut Dirjen Cipta Karya meliputi: jalan lingkungan, jalan setapak, kran umum, sumur gali, drainase, Mandi Cuci Kakus (MCK) dan Tempat Pembuangan Sampah (TPS). Penyebutan prasarana biasanya dikaitkan dengan sarana. Jika prasarana atau infrastruktur menunjuk alat utama bagi kegiatan sosial ekonomi, maka sarana adalah alat pembantu dalam prasarana. Sarana lingkungan adalah segala sesuatu yang dapat dipakai sebagai alat untuk mencapai maksud dan tujuan. Sedag menurut Undang-undang Nomor 14 Tahun 1992, sarana lingkungan adalah fasilitas penunjang. yang berfungsi untuk penyelenggaraan dan pengembangan kehidupan ekonomi, sosial budaya, sarana lingkungan berupa fasilitas pendidikan, kesehatan, perbelanjaan pemerintah dan pelayanan umum, peribadatan, rekreasi dan kebudayaan, olahraga dan lapangan terbuka.

\section{Keadaan Penduduk}

Jumlah penduduk Desa Doulu Menurut data BPS Kecamatan Berastagi tahun 2015, Desa Doulu berpenduduk sekitar 2.236 jiwa, laki-laki 1.167 jiwa dan perempuan 1069 jiwa, dengan jumlah kepala keluarga sekitar 629 Kepala Keluarga untuk keseluruhan dan 208 Kepala Keluarga di Desa Doulu Pasar sedangkan 421 Kepala Keluarga. Sekitar 1.008 jiwa (45.5\%) masyarakat Desa Doulu menganut agama Islam, sementara sekitar 905 jiwa (40,8\%) menganut agama Kristen Protestan dan sisanya beragama Kristen Katolik sekitar 323 jiwa (13.6\%). Di daerah ini juga terdapat 4 tempat ibadah diantaranya adalah mesjid dan 2 gereja GBKP di masing-masing desa dan 1 gereja Katolik di Desa Doulu.

Tabel 1. Tingkat Pendidikan Masyarakat Desa Doulu

\begin{tabular}{|l|l|l|l|l|l|l|l|}
\hline \multirow{2}{*}{ Tahun } & \multicolumn{7}{|c|}{ Pendidikan } \\
\cline { 2 - 7 } & $\begin{array}{l}\text { Tidak } \\
\text { Sekolah }\end{array}$ & $\begin{array}{l}\text { Belum } \\
\text { SD }\end{array}$ & Tamat & SD & SMP & SMA & Sarjana \\
\hline 2015 & 230 & 187 & 570 & 505 & 671 & 73 \\
\hline 2016 & 230 & 187 & 600 & 534 & 696 & 77 \\
\hline 2017 & 230 & 187 & 634 & 567 & 727 & 79 \\
\hline 2018 & 230 & 187 & 664 & 597 & 757 & 85 \\
\hline 2019 & 230 & 187 & 691 & 624 & 784 & 88 \\
\hline
\end{tabular}


Strategi Komunikasi Pembangunan...Imam El Islamy 
Pada umumnya mata pencaharian masyarakat Desa Doulu adalah bertani yaitu sekitar 1.000 jiwa (49.2\%). Ini dikarenakan, secara umum kehidupan masyarakat di Desa Doulu bersifat Agraris. Hasil pertanian merupakan sumber penghidupan pokok bagi kebanyakan penduduk desa. Hampir setiap masyarakat di Desa Doulu ikut terlibat dalam mengelola lahan pertanian seperti menggarap sawah untuk ditanami padi dan lahan perladangan untuk ditanami tanaman jangka pendek seperti tomat, sayur kol, cabe merah, cabe hijau, sawi hijau, strawbery serta tanaman tua seperti coklat, kopi dan sebagainya. Sedangkan sisanya ada yang bekerja sebagai pedagang 400 jiwa (25.21\%), sebagai Pegawai Negeri dan Swasta 30 jiwa sekitar (6.9\%) dan pekerjaan lainnya 150 jiwa. ( $18.7 \%$ )

Desa Doulu juga terkenal akan pemandian air panasnya, Pada awalnya kawasan ini memiliki status Cagar Alam berdasarkan keputusan Raja Deli tanggal 30 Desember 1924, yang kemudian dirubah statusnya menjadi taman wisata alam melalui surat keputusan Menteri Pertanian nomor 320/Kpts/Um/5/1980 tanggal 9 Mei 1980 dengan luas 7 hektare. Sejak diputuskan menjadi taman wisata alam banyak masyarakat yang memanfaatkan ini untuk meningkatkan kehidupan melalui berdagang.

\section{METODOLOGI}

Metode Participatory Rural Appraisal (PRA) yaitu pengkajian keadaan desa secara partisipatif, yang menghargai dan mengimplementasikan prinsip-prinsip pemberdayaan bagi masyarakat. ${ }^{5}$ Participatory Rural Apprasial (PRA) memungkinkan orang-orang desa menganalisis situasi, secara optimal merencanakan dan melaksanakan tekad itu di desanya sendiri sehingga PRA adalah penilain pedesaan yang partisipatoris. 6 Pengumpulan data dengan observasi langsung, wawancara dan Focus Group Discussion (FGD) dan dokumentasi. Prosedur pelaksanaannya yaitu observasi dan wawancara dilakukan sepanjang proses penelitian berlangsung yaitu (1) Mulai dari studi pendahuluan dalam mengamati, mengunpulkan informasi dan data, menganalisis suatu daerah yang akan dijadikan lokasi penelitian, pembukaan akses atau pendekatan, termasuk perumusan masalah, tujuan penelitian dan desain penelitian. (2) Ketika proses pelaksanaan sebelum dan sesudah FGD. (3) Pada saat melakukan verifikasi data dan triangulasi hasil penelitian.

\footnotetext{
5 Syahyuti. Tiga Puluh Konsep Penting dalam Pembangunan Pedesaan dan Pertanian. (Jakarta : Bina Rena Pariwara, 2006 ) hal. 47

${ }^{6}$ Mikkelsen, B. Metode Penelitian Partisipatoris dan Upaya Pemberdayaan, Nalle M, penerjemah. ( Jakarta : Yayasan Pustaka Obor Indonesia., 2011 ) hal. 39. Terjemahan dari : Methode for Development Work and Research : A Guide for Practitioners. Sage Publications Inc
} 


\section{HASIL DAN PEMBAHASAN}

Perwujudan perjuangan otonomi di desa yaitu berlakuknya Undang-Undang Nomor 6 Tahun 2014 tentang Desa khususnya Pasal 1 ayat (8) bahwa pembangunan desa adalah upaya peningkatan kualitas hidup dan kehidupan yang sebesar-besarnya untuk kesejahteraan masyarakat desa. Pasal 78 ayat (1) Pembangunan desa bertujuan meningkatkan kesejahteraan masyarakat desa dan kualitas hidup manusia serta penanggulangan kemiskinan melalui pemenuhan kebutuhan dasar, pembangunan sarana dan prasarana desa, pengembangan potensi ekonomi lokal, serta pemanfaatan sumber daya alam dan lingkungan secara berkelanjutan. Pada ayat (3) pembangunan desa mengedepankan kebersamaan, kekeluargaan, dan kegotongroyongan guna mewujudkan perdamaian dan keadilan sosial. Desa merupakan miniatur pembangunan negara, sehingga eksistensi dan peran desa sangat menentukan bagi kesejahteraan masyarakat. Menurut Adisasmita pembangunan pedesaan merupakan bagian integral dari pembangunan nasional. ${ }^{7}$

Semangat membangunan desa yang termaktub dalam undang-ndang desa tersebut merupakan konsep komunikasi pembangunan partisipatif yang intinya masyarakat terlibat menjadi pelaku utama mulai dari perencanaan, pelaksanaan dan evaluasi pembangunan atau disebut people centered development. Syahyuti menyatakan konsep pembangunan partisipatif (participatory development) adalah proses pelibatan masyarakat secara aktif dalam seluruh keputusan subtansial yang berkenaan dengan kehidupan. ${ }^{8}$ Menurut Rangkuti paradigma pembangunan mengalami perubahan yaitu menitikberatkan pada pemberdayaan yang dikenal dengan pembangunan manusia (people centered development), pembangunan berbasis sumber daya lokal (resource based development) dan pembangunan kelembagaan (institutional development). ${ }^{9}$

\section{a. Peran Masyarakat Dalam Pembangunan Desa (Marsipature Hutanabe)}

Konsep pembangunan Marsipature Hutanabe yang dicetuskan oleh almarhum Gubernur Sumatera Utara yakni Raja Inal Siregar, sangat berkaitan dengan konsep komunikasi pembangunan partisipatif. Prinsip kembali ke kampung halaman untuk membangun kampung sendiri itu merupakan proses dari pelibatan masyarakat desa untuk pembangunan baik dari sisi pendidikan, ekonomi maupun spiritual. Marsipature Hutanabe yang digaungkan oleh mantan Gubernur Sumut itu masih melekat sampai sekarang terutama masyarakat adat batak di

\footnotetext{
7 Adisasmita, R. Membangun Desa Partisipatif. (Yogyakarta: Graha Ilmu, 2006) hal. 34

8 Syahyuti. Tiga Puluh Konsep.. hal. 103

${ }^{9}$ Rangkuti, F. Analisis SWOT: Teknik Membedah Kasus Bisnis. ( Jakarta : Gramedia, 2006 ) hal. 77
} 
tanah Karo, itu terlihat dari banyaknya pemilik tempat wisata pemandian air panas yang dimiliki oleh orang asli Doulu, sekitar 10 tempat pemandian air panas di desa Doulu 9 diantaranya dimiliki oleh orang asli Doulu, 1 dimiliki oleh investor luar negeri (China).

Desa Doulu juga akan memiliki Islamic Centre (Kampoeng Dakwah) yang dibangun oleh orang asli desa Doulu bernama Mulia Purba, kepedulian orang asli desa Doulu ini untuk membangun daerahnya sesuai dengan konsep Marsipature Hutanabe. Konsep Partisipatif dalam komunikasi pembangunan dapat dilihat dengan metode SWOT. ${ }^{10}$ Analisis SWOT yang disajikan pada Tabel 1, yaitu (1) Faktor internal yang terdiri dari Strength (kekuatan) dan Weakness (kelemahan). (2) Faktor eksternal terdiri dari Opportunity (peluang) dan Threats (ancaman). Analisis SWOT digunakan untuk membuat strategi komunikasi pembangunan partisipatif dalam pembangunan desa khususnya program pemberdayaan bagi masyarakat.

\section{b. Peran Pemerintah Desa terhadap Pembangunan Masyarakat}

Pemerintah desa kurang memberikan kesempatan bagi masyarakat untuk beraspirasi untuk menentukan perumusan program dan anggaran pembangunan desa. Aspirasi dan proses pembuatan keputusan diwakili oleh para perangkat RW, Badan Perwakilan Desa dan perangkat tanpa memperhatikan aspirasi masyarakat dalam membuat program dan anggaran pembangunan desa. Parkinson dan Mansbridge (2012) membangun sistem demokrasi deliberatif dapat dilakukan dengan cara pemerintah meningkatkan pendelegasian kewenangan dari ranah elit ke ranah publik dan berkomitmen untuk mematuhi keputusan dari publik. Pemerintah desa kurang memiliki idealisme dan inisitaif untuk membuat program dan anggaran program pemberdayaan masyarakat desa untuk membuka lapangan kerja dengan mengembangkan potensi masyarakat desa seperti pertanian, pariwisata dan perdagangan.

Pemerintah desa memiliki kekuasaan yang kuat untuk menentukan semua program dan anggaran pembangunan, tanpa memberikan kesempatan secara terbuka bagi keterlibatan masyarakat, mengakibatkan kultur yang ada kurang demokratis, partisipatif, transparan dan akuntabel dalam proses pembangunan. ${ }^{11}$ menyatakan pendekatan partisipasi sangat penting bagi masyarakat di daerah, karena lebih mengetahui dan mampu mengidentifikasi permasalahan, potensi, dan

${ }^{10}$ Dyson, R.G. (2004). Strategic development and SWOT analysis at the University of Warwick. ( European Journal of Operational Research. 2004 ) hal. 631-640

${ }^{11}$ Purwatiningsih, S.D. Efektivitas Komunikasi Pembangunan pada Masyarakat Sekitar Hutan Konservasi Taman Nasional Gunung Halimun Salak. Disertasi. Bogor: Institut Pertanian Bogor, 2008 ) hal. 93. 
kebutuhan wilayahnya mulai dari perencanaan, pelaksanaan, serta penilaian suatu pembangunan. Pemerintah desa belum memanfaatkan forum Musyawarah Perencanaan Pembangunan (Musrenbang) di tingkat desa untuk membuat perencanaan program pembangunan yang beorientasi pada pemberdayaan masyarakat desa yang memanfaatkan potensi sumber daya manusia, sumber daya alam dan sumber dana dari Alokasi Anggaran Desa (ADD) supaya menciptakan lapangan kerja atau usaha ekonomi di desa.

Hal ini terbukti dengan tidak termanfaatkan secara maksimal sumber daya alam yang dimiliki oleh desa Doulu, dana desa yang di kucurkan oleh pemerintah digunakan untuk pembangunan infrastruktur saja seperti parit, penampungan air, dan bantuan kerumah ibadah. Penggunaan anggaran seperti ini dianggap tidak efektif untuk pembangunan karena kebutuhan masyarakat yang ada di desa Doulu berbeda dengan kebutuhan masyarakat di desa lainnya. Program pemberdayaan yang selama ini diberikan pada masyarakat desa masih bersifat top down yaitu inisiatif dari program dinas kabupaten dan belum berkesinambungan. Pemerintah desa masih pasif dan tidak memiliki inisiatif dalam membuat serta menganggarkan program pemberdayaan bagi masyarakat desa, sehingga masyarakat terpicu untuk kembali ke desa dan membangun desa Doulu. Dengan demikian, diperlukan model pemberdayaan masyarakat dan monitoring serta evaluasi pembangunan di desa, sebagaimana menurut Theodore. 
Tabel 2. Analisis SWOT dan Strategi Komunikasi Pembangunan Partisipatifdi Desa Doulu dan Kabupaten Karo

\begin{tabular}{|c|c|c|}
\hline Fakor Eksternal & \begin{tabular}{l}
\multicolumn{1}{c}{ Strength (S) } \\
1. Masyarakat memiliki \\
motivasi yang tinggi untuk \\
bekerja keras \\
2. Masyarakat memiliki \\
kemampuan dan potensi \\
dalam proses pembangunan \\
desa bidang pertanian, \\
perdagangan dan pariwisata \\
3. Masyarakat memiliki \\
keinginan dan harapan besar \\
memperoleh pemberdayaan \\
untuk meningkatkan \\
pengetahuan dan kemampuan \\
dibidang pertanian, \\
Pariwisata dan Perdagangan \\
4. Masyarakat memiliki ikatan \\
yang kuat untuk tinggal, \\
\end{tabular} & \begin{tabular}{l}
\multicolumn{1}{c}{ Weakness $(\mathbf{W})$} \\
1. Mastarakat memiliki tingkat \\
pendidikan yang rendah \\
sehingga tidak memiliki daya \\
tawar. serta kemampuan yang \\
terbatas mengelola usaha di \\
desa. \\
2. Masyarakat desa kurang \\
memiliki keberanian \\
beraspirasi terhadap \\
pemerintah desa untuk \\
mengusulkan program \\
pembangunan desa dan \\
pemberdayaan masyarakat \\
3. Masyarakat tidak melakukan \\
kerjasama membentuk lembaga \\
ekonomi di desa \\
A Macvaralat dalam \\
\end{tabular} \\
\hline \multirow[b]{2}{*}{ 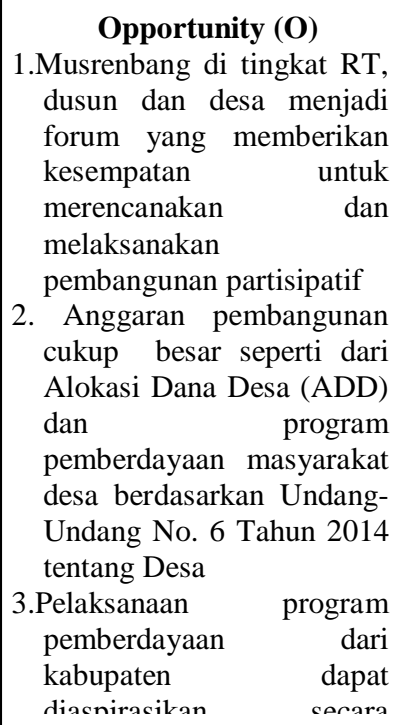 } & \multirow[b]{2}{*}{$\begin{array}{l}\text { Strategi SO } \\
\text { Pemerintah Kabupaten Karo, } \\
\text { Perguruan Tinggi dan } \\
\text { media/jurnalis melakukan } \\
\text { komunikasi partisipatif berupa: } \\
\text { 1.Memberikan kesempatan } \\
\text { pada masyarakat dalam } \\
\text { forum rembug desa atau } \\
\text { Musyawarah desa supaya } \\
\text { dapat beraspirasi secara } \\
\text { terbuka, sejajar dan mufakat } \\
\text { dalam mengembangkan } \\
\text { potensi, minat, kebutuhan, } \\
\text { harapan masyarakat untuk } \\
\text { pembangunan desa dan } \\
\text { pemberdayaan di berbagai } \\
\text { bidang. } \\
\text { 2.Memberikan sosialisasi dan } \\
\text { pelatihan pada masyarakat } \\
\text { n.mnn mmmnnn... mnnt.1 }\end{array}$} & \multirow[b]{2}{*}{ 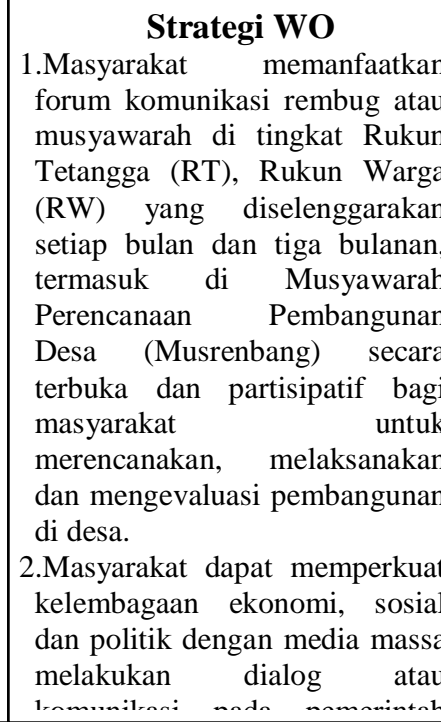 } \\
\hline & & \\
\hline Threats (T) & \multirow[b]{2}{*}{$\begin{array}{l}\text { Strategi ST } \\
\text { Perguruan tinggi dan lembaga } \\
\text { swadaya masyarakat membuat } \\
\text { kegiatan komunikasi } \\
\text { pemberdayaan secara } \\
\text { partisipatif yaitu penyuluhan, } \\
\text { pelatihan \& pendampingan } \\
\text { kepada masyarakat tentang } \\
\text { 1.Mekanisme Musrenbang desa } \\
\text { untuk mengidentifikasi } \\
\text { masalah, potensi, merancang } \\
\text { program pemberdayaan, serta } \\
\text { anggarannya } \\
\text { 2. Pengembangan dan } \\
\text { penguatan lembaga ekonomi, } \\
\text { sosial \& politik sebagai } \\
\text { penyeimbang kekuasaan dan } \\
\text { kontrol di desa. }\end{array}$} & Strategi WT \\
\hline $\begin{array}{lrr}\text { 1.Pemerintah desa } & \text { masih } \\
\text { elitis dan } & \text { kurang } \\
\text { demokratis } & \text { untuk } \\
\text { memberikan } & \text { kesempatan } \\
\text { beraspirasi serta } & \text { kurang } \\
\text { transparan } & \text { dalam } \\
\text { pelaksanaan } & \text { program } \\
\text { pembangunan dan alokasi } \\
\text { anggaran } \\
\text { 2.Pemerintah desa kurang } \\
\text { memiliki inisiatif untuk } \\
\text { membuat program } \\
\text { pemberdayaan dan alokasi } \\
\text { anggaranya, hanya } \\
\text { menunggu dari pihak } \\
\text { kabupaten. }\end{array}$ & & 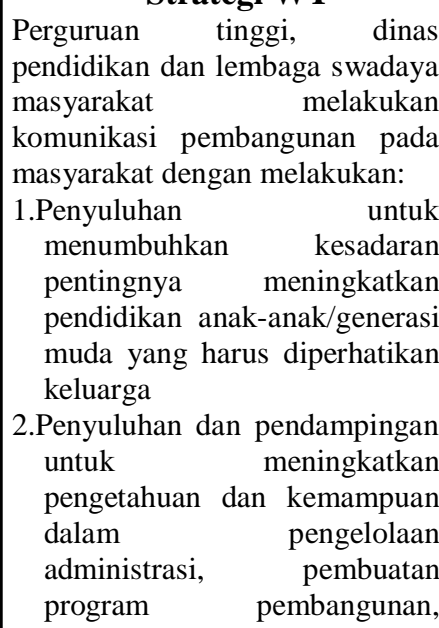 \\
\hline
\end{tabular}


Berdasarkan hasil analisis SWOT tentang peran masyarakat dan pemerintah desa dalam pembangunan di Desa Doulu Kabupaten Karo, ditemukan bahwa komunikasi pembangunan antara masyarakat dengan pemerintah desa belum partisipatif. Masyarakat dan pemerintah desa masih memiliki budaya patrimonial dengan memposisikan pemerintah desa sebagai atasan, penguasa yang mendominasi kepurusan membuat program pembangunan dan anggarannya. Pihak masyarakat berposisi sebagai bawahan yang tidak sejajar, harus menuruti dan pasrah menerima keputusan yang diberikan pemerintah desa.

Demokratisasi di desa belum terwujud, seperti kurang adanya kesempatan untuk beraspirasi, berpartisipasi, tidak ada keterbukaan atau transparansi dan akuntabilitas dari pemerintah desa dalam melakukan perencanaan, penganggaran dan pelaksanaan pembangunan di desa. Pola komunikasi linear (searah) cenderung tidak efektif untuk mengembangkan prasyarat partisipasi (kesempatan, kemampuan dan kemauan) warga desa. Akibatnya partisipasi masyarakat rendah, karena program tidak sesuai dengan kebutuhan masyarakat. Untuk meningkatkan partisipasi masyarakat dapat melalui proses komunikasi yang lebih interaktif dan konvergen. Pemerintah perlu menetapkan pendekatan partisipatif yang bertumpu pada kelompok masyarakat, dan perlu merubah paradigma komunikasi top-down ke bottom-up.

Pemerintah desa tidak memiliki inisiatif untuk membuat program pemberdayaan bagi masyarakat, yang selama ini merupakan program dari dinas pemerintah kabupaten. Program pemberdayaan yang dilakukan tidak secara partisipatif melibatkan masyarakat sesuai permasalahan yang dihadapi, kebutuhan, dan potensi sumber daya masyarakat, budaya serta ekonomi di desa. Program pemberdayaan yang dilakukan atas inisitif dinas pemerintah daerah tidak secara berkesinambungan yaitu pada tahapan penyuluhan dan pelatihan, tetapi tidak dilanjutkan dengan program pendampingan, monitoring dan evaluasi, serta kemitraan untuk membantu peningkatan jaringan kelembagaan.

Strategi yang dapat dirancang sesuai hasil analisis SWOT terhadap peran masyarakat dan pemerintah desa yaitu strategi komunikasi pembangunan partisipatif yaitu bersifat terbuka, sejajar, dialogis, menghasilkan keputusan bersama secara mufakat. Persyaratannya yaitu masyarakat desa memiliki karakter aspiratif dengan memberikan masukan atau kritikan, partisiptif dengan aktif terlibat dalam segala kegiatan pembangunan di desa dan kolaboratif yaitu dapat bersatu untuk bekerjasama baik antar masyarakat maupun antar lembaga masyarakat. Pemerintah desa dalam menjalankan strategi komunikasi pembangunan partisipatif persyaratannya harus memiliki karakter responsif yaitu cepat tanggap dan peduli pada masukan, kritikan dan masalah yang ada, sifat transparan yaitu terbuka untuk menerima saran, kritik dan alokasi anggaran pembangunan pada publik, serta bersifat akuntabel yaitu dapat mempertanggung jawabkan pelaksanaan pembangunan kepada publik. menyatakan komunikasi partisipatif merupakan salah satu pendekatan untuk mewujudkan tujuan pembangunan melalui partisipasi aktif masyarakat untuk mengaspirasikan kebutuhan dengan dukungan kebijakan dan intervensi pemerintah berupa program pembangunan. ${ }^{12}$

12 Muchtar, K. Penerapan Komunikasi Partisipatif pada Pembangunan di Indonesia. Jurnal Makna. 1(1), 2006. 20-32. 
Menurut Mahmud (2007) perlu penerapan pola komunikasi dalam pembangunan secara persuatif, dialogis dan deliberatif dengan memberi peluang bagi keikutsertaan publik, membentuk forum lokal terutama lembaga keagamaan dapat dijadikan sebagai media komunikasi dan penyebaran informasi perdesaan karena lebih fleksibel terhadap prinsip keikutsertaan, keterbukaan, rutinitas dan kohesivitas. Dengan demikian strategi komunikasi pembangunan partisipatif dapat diimplementasikan oleh masyarakat dalam forum rembug atau pertemuan tingkat Rujun Tetangga (RT), Rukun Warga (RW) dan dusun, forum rapat menyusun Anggaran Pendapatan Belanja Desa (ABBDes) oleh pemerintah desa dan Badan Permusyawaratan Desa (BPD), kemudian dalam Musyawarah Perencanaan Pembangunan (Musrenbang) desa dalam perencanaan, pelaksanaan, penganggaran, pengawaan dan evaluasi pembangunan di desa. Strategi komunikasi pembangunan partisipatif menjadi pendekatan untuk merancang dan melaksanakan pemberdayaan masyarakat desa dengan tahapan sosialisasi, penyuluhan, pendampingan, pelatihan, kemitraan dan kemandirian. Pemberdayaan dirancang sesuai dengan identifikasi masalah, potensi sumber daya manusia, ekonomi, budaya dan lingkungan, kemudian dapat dianalisis solusi serta dihasilkan program peberdayaan yang dibutuhkan.

\section{KESIMPULAN}

Komunikasi pembangunan antara masyarakat dan pemerintah Desa Doulu Kabupaten Karo belum partisipatif, indikasinya kurang memberikan kesempatan secara terbuka untuk beraspirasi dan partisipasi dalam merencanakan, melaksanakan serta evaluasi pembangunan termasuk dalam program pemberdayaan masyarakat. Pemberdayaan masyarakat belum dirumuskan dalam perencanaan program pembangunan di desa dan masih bersifat top down karena inisiatif kegiatan dengan anggarannya dari dinas pemerintah daerah Kabupaten Karo, bukan berasal dari aspirasi masyarakat dan pemerintah desa yang bersifat partisipatif (bottom up). Namun pemerintah desa seakan bergantung kepada orang asli desa Doulu untuk membangun daerahnya karena investasi serta kepedulian terhadap kampung halaman mereka (Marsipature Hutanabe). Pemerintah desa seharusnya meapresiasi orang asli Doulu yang ingin membangun kampung halamannya dengan melibatkan masyarakat dalam merencanakan pembangunan desa.

Masyarakat dan pemerintah desa harus mendapat sosialisasi dan pelatihan dari pemerintah daerah, perguruan tinggi dan lembaga swadaya masyarakat tentang mekanisme Musyawarah Perencanaan Pembangunan (Musrenbang) desa, membuat program pembangunan, penggunaan dan pelaporan anggaran, dan evaluasi pembangunan. Masyarakat dan pemerintah desa harus dapat memanfaatkan forum pertemuan dari tingkat RT, RW, dusun dan desa untuk menciptakan komunikasi pembangunan partisipatif yang melibatkan semua pihak, terbuka, sejajar, dialogis, dan menghasilkan kesepakatan bersama menyusun program dan anggaran pembangunan desa. Pemerintah desa, masyarakat, perguruan tinggi dan lembaga swadaya masyarakat dapat bekerjasama melakukan identifikasi masalah, potensi sumber daya alam, manusia, budaya dan ekonomi di desa untuk dijadikan modal 
pembangunan, menciptakan solusi dengan membuka lapangan kerja di desa yang dapat meningkatkan kesejahteraan di desa.

\section{DAFTAR PUSTAKA}

Adisasmita, R. 2006. Membangun Desa Partisipatif. Yogyakarta: Graha Ilmu Brooks, G., Heffner, A., \& Henderson, D. 2014. A SWOT analysis of competitive knowledge from social media for a small start-up business. Review of Business Information Systems. 18(1), 23-34

Dhak, B. 2014. Food security act, 2013: Oppurtunities and challenges for the Backward States in India. Journal of Rural Development. 33(4), 475 - 491

Dyson, R.G. 2004. Strategic development and SWOT analysis at the University of Warwick. European Journal of Operational Research. 152, 631-640

Mikkelsen, B. 2011. Metode Penelitian Partisipatoris dan Upaya Pemberdayaan, Nalle M, penerjemah. Jakarta : Yayasan Pustaka Obor Indonesia. Terjemahan dari : Methode for Development Work and Research : A Guide for Practitioners. Sage Publications Inc.

Muchtar, K. 2016. Penerapan Komunikasi Partisipatif pada Pembangunan di Indonesia. Jurnal Makna. 1(1), 20-32.

Mulyana, D. 2007. Membangun Komunikasi Pembangunan yang Humanistik [Kata Pengantar]. Di dalam Dilla S, penulis. Komunikasi Pembangunan : Pendekatan Terpadu. Bandung : Simbiosa Rekatama Media.

Nugroho, A. 2009. Komunikasi Pembangunan dan Keterbukaan Informasi Publik dalam Kerangka Pengembangan Masyarakat Mandiri. Prosiding Seminar Nasional: Komunikasi Pembangunan Mendukung Peningkatan Kualitas Sumber Daya Manusia dalam Kerangka Pengembangan Masyarakat. Kamis, 19 November 2009. Bogor : IPB International Convention Center (IPB ICC), hal : 61-66.

Purwatiningsih, S.D. 2012. Efektivitas Komunikasi Pembangunan pada Masyarakat Sekitar Hutan Konservasi Taman Nasional Gunung Halimun Salak. Disertasi. Bogor: Institut Pertanian Bogor.

Rangkuti, F. 2006. Analisis SWOT: Teknik Membedah Kasus Bisnis. Jakarta : Gramedia.

Rogers, E.M. 1976. Perspektif Baru dalam Komunikasi dan Pembangunan : Suatu Tinjauan dalam Komunikasi dan Pembangunan Perspektif Kritis, Dasmar N, penerjemah. 1985. Jakarta: LP3ES. Terjemahan dari Communication and Development : Critical Perspectives.

Syahyuti. 2006. Tiga Puluh Konsep Penting dalam Pembangunan Pedesaan dan Pertanian. Bina Rena Pariwara. Jakarta

Theodore, N., Valenzuela, Jr, A., \& Meléndez, E. 2009. Worker centers: d efending labor standards for migrant workers in the informal economy. International Journal of Manpower. 30(5),422 - 436 